\title{
Islamic Business Ethics As A Practical Solutions In The Scope Of E-Commerce Business
}

\author{
Havis Aravik', Luis Marnisah , Achmad Irwan Hamzani3 \\ ${ }^{12}$ Sekolah Tinggi Ekonomi dan Bisnis Syariah (STEBIS) Indo Global Mandiri \\ Palembang, 3 Universitas Pancasakti Tegal \\ 3 Jl. Halmahera No.KM, Mintaragen, Kec. Tegal Tim., Kota Tegal, Jawa Tengah \\ Jl. Jend. Sudirman No.KM.4, RW.No.629, 20 Ilir D. IV, Kota Palembang \\ Email: havis@stebisigm.ac.id, luismarnisah@uigm.ac.id, \\ al hamzani@upstegal.ac.id
}

\begin{abstract}
Abstrak
Penelitian ini membahas etika bisnis Islam sebagai solusi praktis dalam lingkup ecommerce. Tujuan penelitian untuk menjawab bagaimana solusi yang ditawarkan etika bisnis terhadap ruang lingkup bisnis e-commerce. Penelitian ini menggunakan pendekatan kepustakaan (library research) dengan cara mendeskripsikan dan menganalisis objek penelitian yang berkaitan dengan topik, kemudian dianalisis dan terakhir ditarik kesimpulan serta dideskripsikan dalam bentuk laporan tertulis. Hasil penelitian menunjukkan bahwa Islam sebagai agama rahmatan lil alamen telah memberikan tuntunan kepada setiap manusia, khususnya kepada seluruh umat Islam, bahwa dalam aktivitas bisnis terdapat etika Islam yang melekat di dalamnya, termasuk dalam lingkup e-commerce. Etika tersebut dimaksudkan agar kegiatan bisnis tidak semata-mata menghasilkan keuntungan materil tetapi lebih dari itu memberikan manfaat lebih sehingga tercapai baik di dunia maupun di akhirat. Oleh karena itu, Islam sangat mengatur berbagai kegiatan bisnis seperti produksi, konsumsi, perdagangan, persaingan dalam bisnis hingga memasarkan suatu produk kepada konsumen. Semua etika ini sangat penting dalam kegiatan bisnis e-commerce.
\end{abstract}

\section{Kata Kunci: Etika Bisnis, Islam, E-Commerce}

\begin{abstract}
This article discusses Islamic business ethics as a practical solution in the scope of ecommerce. With the objective of the research to answer how the solutions offered by business ethics to the scope of the e-commerce business. This study used a literature approach by describing and analyzing research objects, later analyzed and finally drawing conclusions. The results of this study show that Islam as rahmatanlilalamien religion has provided guidance to every human being, especially to all Muslims, that in business activities there is an Islamic ethic inherent in it, including in the scope of ecommerce. The ethics are intended that business activities do not solely produce material benefits but more than that it gives more benefits so that it is achieved in both the world and the hereafter. Therefore, Islam really regulates various business activities such as production, consumption, trading, competing in business to market a product to consumers.
\end{abstract}

\section{Keywords; Business Ethics, Islam, E-Commerce}




\section{Islamic Business Ethics As A Practical Solutions \\ In The Scope Of E-Commerce Business}

Havis Aravik, dkk

\section{INTRODUCTION}

One of the crucial issues faced today is the industrial revolution of 4.0. Principally the industrial revolution began in the invention of the engine so that gasoline-powered cars replaced horse-drawn carriages in the early 2oth century, the world slowly witnessed the waning of wood car workshops and horse farms. Horse-drawn carriages turn into gasoline-engined iron chariots. Now the world is witnessing the shift from gasoline-powered cars to self-driving cars controlled by information technology (internet) via smartphones (Kasali, 2017) at this stage the world enters the industrial revolution 4.0.

The industrial revolution has changed the way humans work into automation or digitalization through innovations. The industrial revolution 4.0 is present and brings about the phenomenon of disruption, a situation where the movement of the industrial world or work competition is no longer linear. Disruption initiates the birth of a new business model with a more innovative and disruptive strategy (Suwardana, 2018). One of them is in the scope of ecommerce which is a transaction of goods and services carried out through electronic systems or social media such as Whatsapp, Facebook, Instagram, and other computer networks. As a result, various sectors become electronic offices or electronic storefronts such as e-commerce for entrepreneurs who run online businesses.

In general, e-commerce business creates many problems, especially in aspects of the rules of the game which even nowadays it has not been mutually agreed upon, and the legal regulations that protect them are also not yet available. Consequently, there are many cases involving consumers and producers, ranging from ordered goods that have been received, ordered goods are not in accordance with what was received, consumers are being lied to, misdirected information, unfair competition, monopoly and so forth.

Starting from the above problems, the study of Islamic business ethics is very important as one of the solutions in the field of e-commerce. At this point, Islamic business ethics can be a bridge to various problems arising from online trading activities. With good security of various Islamic business ethics, it is expected to minimize various violations of economic activities that impact on 
the destruction of economic harmony and the relationship between sellers and buyers.

\section{RESEARCH METHODOLOGY}

This research is a type of qualitative research that uses library research methods. Library research is research that is carried out using literature, either in the form of books, notes, or other reference sources. Data collection techniques in this study are about discourse through books, articles, journals, web (internet), and other information related to the research title to find things related to the themes discussed. This study uses data analysis in the form of content analysis. This method is used to analyze the meaning contained in Islamic business ethics as a solution in e-commerce business practices. The data generated is descriptive data, namely written words that are presented in a narrative manner.

\section{Basic Concepts of Islamic Business Ethics}

Business is an activity carried out by a person or group of people to provide goods and services with the aim of obtaining profits. People who try to use their time by taking risks in carrying out business activities are usually called entrepreneurs (Sudaryono, 2015). While ethics is a supporting component of business people, especially in terms of personality, actions and behavior (Kadir, 2013). Ethics are also referred to as signs within a community group that will be able to guide and remind their members of good conduct that must be obeyed and carried out.

Ethics in business has been agreed upon by people in business groups and other related groups. That is what is then used as a reference for realizing goals in business, among others: giving awareness in every business person to the ethical dimension in business, introducing moral arguments in the economic and business fields as well as how to arrange them, and helping to determine moral attitudes is right in carrying out the profession.

Business ethics is a knowledge that is needed by many parties but is still problematic from a methodological point of view. This knowledge is needed to change the performance of the business world which is filled with mal-business practices. What is meant by mal-business practice is covering both business 


\section{Islamic Business Ethics As A Practical Solutions \\ In The Scope Of E-Commerce Business}

Havis Aravik, dkk

crimes and business tort, namely business crimes as a business activity that violates the law (criminal) or business tort as a business activity that violates ethics

According to Muhammad Saifullah (Saifullah, 2011) business ethics is a set of ethical principles that distinguish good from bad, must, right, wrong, and so forth and general principles that justify someone to apply them to anything in the business world. In another sense, business ethics means a set of principles and norms that business people must uphold in dealing, behaving, and relating to achieving business goals safely (Ahmad Yusuf Marzuqi, 2010)

Because business activities are activities that involve humans, related to humans who have feelings. This means that norms or values that apply well or are considered good in society, inevitably also must be brought along in one's business activities and life. Business ethics is also interpreted as imposing religious norms on the business world, installing codes of business professional ethics, revising economic systems and laws, improving skills in meeting the ethical demands of outsiders to seek safety, and so on. Ethical business is a business that has a commitment to sincerity in maintaining existing social contracts (Zamzam, H. F., \& Aravik, 2020).

From an economical point of view, a good business is a business that brings many benefits. However, in the prospecting for profit in business is not onesided so that the business takes place as a profitable interaction for both parties involved, then a good business must meet ethical standards. This means that in doing business, it can remain on its goal, which is to look for profit, but ethical values are needed in business.

From the various dialectics above, it can be understood that business ethics are rules that are closely related to general norms and principles that apply in society that aim to provide a sense of security and comfort for those who carry out business activities in which involving legal aspects, ownership, management, and distribution of assets.

Business ethics directs business people to always pay attention to the interests of stakeholders in order to carry out their business activities. Stakeholders are a combination of internal and external groups. The internal group consists of company owners, managers, and employees, while the 
external group consists of investors, consumers, non-consumer communities, distributors. By paying attention to the interests of stakeholders, it is expected that business interactions will avoid environmental damage, fraud, misleading promotions, dismissal of employees and so on. All business activities are integrated to improve the welfare of stakeholders while the businessman gains his business profits.

In an Islamic perspective, business and ethics should not be seen as two opposites, because business which is a symbol of worldly affairs is also considered an integral part of things that are of an afterlife investment. That is, if the business orientation and investment efforts are hereafter (intended as worship and constitute the totality of obedience to God), then the business itself must be in line with moral principles based on faith in the hereafter. Even in Islam, the notion of the business itself is not limited to world affairs, but also includes all our activities in the world that are "commercialized" (intended as worship) to gain profit or reward in the hereafter(Ahmad Yusuf Marzuqi, 2010).

Business ethics in Islam has been widely discussed in various literature and its main sources are the Koran and the Sunnah of the Prophet. Moreover, as complete teaching of life, Islam provides guidance on all human activities including in the fields of ethics and economic business. For this reason, business people are expected to act ethically in their various activities. Because according to A. Kadir, (2013) every business undertaken by Muslims can be rewarding worship if it is intended to gain the pleasure of Allah alone. The fiqh rule states; Al-umuru bi mawashidiha (all matters (cases) depend on the purpose). Business in Islam or sharia business is a business based on the Qur'an and hadith in which there is a conformity of business activities with Islamic sharia as worship to Allah Ta'ala to get His pleasure (Agustin, 2017). In other words, business ethics in Islam is a number of ethical business behavior (akhlaq alIslamiyah) which is wrapped in sharia values that promote halal and haram. So ethical behavior is behavior that follows the commands of God and away from prohibition.

Islamic Business is a series of business activities in various forms that are not limited to the number of ownership (goods/services) including profits but are limited in the way to obtain it and the utilization of property due to halal and 


\section{Islamic Business Ethics As A Practical Solutions \\ In The Scope Of E-Commerce Business}

Havis Aravik, dkk

haram rules (QS. Al-Baqarah [2]: 188). So, it would be unwise if a Muslim just works to earn a living, by separating business and worship. A form of appreciation of a Muslim for material spiritualism should be able to guide people to live in a materially sufficient life, and the material is also sufficient to help in the perfection of worship.

Islam does not believe in life which is only oriented to the hereafter without thinking about worldly life, or vice versa only the hereafter. Likewise in running a business (business), the balance of the two values is always a guide for every Muslim businessman who wants success. The paradigm which assumes that in doing business all halal methods are used to get profit is far removed. While business based on Islamic ethics sourced from the Koran and Hadith must always be a priority in every step of the business.

Business actors are required to have an awareness of ethics and morals because both are needs that must be possessed. Business people or companies who are careless and do not maintain ethics, will not do business well so that it can threaten social relations and harm consumers, even himself. Islamic business ethics upholds the spirit of mutual trust, honesty, and justice, while between company owners and employees develop a spirit of kinship (brotherhood) (Aravik, H., \& Hamzani, 2021).

A sharia business must have the following things: First, have an understanding of halal and haram business. A sharia business is demanded to know the facts (tahqiqul manath) on valid and wrong business practices, and must understand the basics of texts that are made as to the law (tahqiqul hukmi). Second, it always based on spiritual values. Ruhaniyah value is the awareness of every human being for its existence as a creation of Allah SWT who must always contract with Him in the form of obedience in every breath of his life.

Third, The correct business practices based on sharia. In this case, there must be a match between Islamic sharia rules and business practices carried out, between what has been understood and applied. So that the consideration is not solely profit and loss materially but it considers business practices that are in accordance with the rules set by Islamic sharia. Fourth, oriented to worship Allah SWT. This orientation is obtained by running the business he /she is 
doing as a worship field and being a reward in the presence of Allah SWT. This is realized if the business always bases on His rules (Agustin, 2017)

If the ethics of Protestant Christianity have created to the spirit (spirit) of Baptism, then Islamic business ethics does not lead to capitalism or socialism. If capitalism emphasizes the individualism of humans and socialism in collectivism, then Islamic business ethics emphasizes four characteristics at once, namely: Unity, equilibrium, freedom (free will), and responsibility (Alma, 2006). Individuals are responsible for the moral effects of their actions, including in economic matters, so that their inner transformation and spiritual growth are closely related to community development (Iqbal, Zamir; Mirakhor, 2011). So it is reasonable if the basic principle of business in Islam is the permissibility of things, where in fact everything is permitted except those which are then prohibited by Islamic teachings

Second, trading in particular, which means trade or sale and purchase between people. Some verses that explain how to deal fairly among humans are summarized in al-Baqarah [2]: 282, an-Nisa '[4]: 29, and an-Nur [24]: 37. In alBaqarah verse, it is mentioned about ethics and procedures for buying and selling, accounts payable, leases, and other transactions. This verse is also used as a guide for accounting activities (the obligation to record transactions) and notarian (the obligation to have the testimony in transactions) in the discussion of Islamic economics and business. So it is hoped that there is a fair and mutually beneficial trade between one party and another, as stated in Surah AnNisa '. And the motive of trading in his rules of worship, because in Surah A-Nur it is stated that someone when making a transaction should always remember Allah, pray and pay zakat. Thus, commerce in a special sense will never escape the activity of remembering God.

From the various opinions above, it can be understood that Islamic business ethics is a business activity that is based on divine rules and aims to always remember God in the context of worship and produce problems not only for himself or others, as well as being kept various actions that are harming others in the hope of getting falah in both the world and the hereafter. 


\section{Islamic Business Ethics As A Practical Solutions \\ In The Scope Of E-Commerce Business}

Havis Aravik, dkk

\section{Islamic Business Ethics as A Solution In The Scope of e-Commerce}

Principally e-Commerce business activities are not new. e-Commerce is the process of buying and selling service products and information that is done electronically by utilizing computer networks such as the internet network. This activity creates many problems such as contracts in business transactions, consumer protection, fraud committed by sellers such as fictitious virtual shops, the condition of purchased goods, and so forth. This basically will not happen if the stakeholders involved in it understand the importance of business ethics in carrying out the e-Commerce business activities.

In order to minimize the various problems above, Islam as a natural rahmatan lil religion provides solutions through Islamic business ethics that has been practiced by the Prophet Muhammad; the best human beings throughout the world in a comprehensive and perfect manner include:

\section{Consumption Ethics}

Consumption of Islam is very oriented to the benefit, so principally the consumption activities of a Muslim must always aim and be bound to the maqasid al-shar'iyyah as the main goal in Islam that leads to the protection of religion, soul, reason, descent and wealth. Therefore, Islam is very concerned with this problem and provides a standard reference of an ideal value system that becomes ethical in consumption, including First, Simple but effective and efficient. This simplicity is one of the characteristics of Allah's merciful servant (Surah al-Furqan [25]: 67). The effective and efficient picture is to use sufficient assets in living and spending and setting priorities according to the maqasid alshar'iyyah. Islam teaches its followers to spend wealth sufficiently and not excessively (QS. Al-A'raf [7]: 31) and as much as possible able to stay away from the miser, mischievous and wasteful, especially when using property (QS. Ali Imran [3]: 167).

Second, Pay attention to the halal and thayyib. Because in Islam the halal and tayyib goods/services consumed are very important because the satisfaction of a consumption behavior according to Islam must be based on the guidance of the teachings of Islam itself (Bahri S., 2014). More than that, the motive of consuming for a Muslim is carrying out the guidance of religious orders. Bearing in mind that the religion of Islam commands eating, drinking, 
dressing, hospitality, and others so that self-damage does not occur (QS. alA'raaf [7]: 31-32). Rasulullah SAW said: "From Anas Bin Malik RA, I have heard Rasullullah say; anyone who wants to be facilitated in finding sustenance and his name is remembered after he died to let him multiply friendship "(HR. Bukhari).

Third, always give thanks to Allah SWT and pay attention to the rights of others. Because of the pleasure a Muslim receives in Islam also cannot be enjoyed alone. Human nature as a social creature is in accordance with the guidance of Islam to also pay attention to other Muslim fellow brothers (Surah Adz-Dzariyat [51]: 19, Al-Baqarah [2]: 267, At-Taubah: 34-35). Fourth, pay attention to cleanliness. Because cleanliness is something that must be maintained by every Muslim, both self, the environment, and other cleanliness. Likewise in consumption, a Muslim must pay attention to cleanliness. The principle of cleanliness implies that the consumed goods must be free from dirt or disease. Likewise must be healthy and have benefits and do not have mudharat (Surah Al-Baqarah [2]: 172) (Bahri S., 2014).

Fifth, pay attention to the suitability of consumption and income. Because the suitability between income and consumption is in accordance with human nature and reality. Therefore, one of the economic axioms is that income is one of the factors influencing individual consumer demand. Where demand increases if income increases and demand decreases if income decreases, accompanied by the persistence of other factors. The suitability between consumption and income is explained in various surah in the Korab such as surah ath-Thalaq [65]: 7 (Bahri S., 2014). Therefore, every Muslim needs to determine the criteria for every item he/she consumes. This is because Muslim consumers have short-term (world) needs and long-term needs (the afterlife). By paying attention to the limited funding sources and being faced with various choices, a household is expected to be able to meet their needs in a balanced manner. These choices can be a combination of the level of consumption between agricultural and industrial goods or between current and future consumption (Machmud, 2017). 


\section{Islamic Business Ethics As A Practical Solutions \\ In The Scope Of E-Commerce Business}

Havis Aravik, dkk

\section{2. $\quad$ Production Ethics}

The main economic problems are production activities and distribution processes, as well as their utilization. For that reason, Islam provides a complete and perfect guide to be used as a legal basis in determining a decision in Islamic law (QS. An-Nisa '[4]: 59), both relating to himself as a person, God's creature, and when interacting with other individuals. Even with himself and the surrounding environment.

As a producer in the field of production, Islam provides guidance with the aim that the efforts it carries contain benefits and blessings both for themselves and others and of course in harmony with divine values. As taught by the Prophet. These guidelines include: First, Not employing underage workers. Because child labor can be categorized as hiring beyond limits. Children's rights are not working, on the contrary, the obligation of parents to care for children and if these obligations cannot be fulfilled then it will be the responsibility of the state. Even so, training children to work is not prohibited, this is seen in the history of the Prophet Muhammad, how he had learned to go from childhood and then took part in trading from an early age.

Second, workers work during certain hours in accordance with the provisions of applicable law. Islam provides clear rules regarding employment contract transactions, whereby Islam provides laws that employers must pay attention to protect workers. Such protection concerns; (a) Protection of workers and adequate rest periods (HR. al-Baihaqy); (b) Livelihood security for workers (HR. al-Nasai); (c) Immediately pay salaries (wages) (HR. Abu Dawud). In fact, Koran surah al-An'am [6]: 145 likens an employer who employs workers beyond his abilities such as squeezing his sweat, making him a driving machine that produces the company's products as having flowing blood. Including sleaze when employing workers at will, even though the company is actually able to pay more (QS. An-Nisa '[4]: 58.

Third, providing a decent wage. Islam views that wages are not limited to rewards given to workers, but there are moral values that refer to the concept of humanity. Employers, in setting wages do not commit tyranny against workers or are wronged by workers (QS. Al-Baqarah [2]: 279). In other words, employers are not allowed to exploit workers and workers cannot exploit their 
employers (Harahap, et al, 2015: 82). In order to avoid discrimination against workers, Islam regulates the problem of improvement in a labor contract law (ijarah) (Zamzam, H. F., \& Aravik, 2020).

Fourth, hastening to give workers rights. Islam warns that workers are not for material rewards only. Focusing only on monetary rewards is not recommended (QS. Al-Mukminun [23]: 72). However, not hastening to give rights to workers including the act of delaying payment of employee salaries for capable employers is an injustice (QS. Ath Thalaq [65]: 6). Fifth, Production which is required and recommended in Islam is a good, productive production and brings blessings. The meaning is that the production carried out is production based on the right creed, the right intention, the work carried out in accordance with the guidance of the Islamic religion, and does not leave the mandatory and special obligation, and the results are beneficial not only for himself, also for society and the environment. Therefore, Islam strictly forbids production that does not provide any benefit for human life, and nature. In other words, production activities are carried out by preserving natural resources by relying on the vision of the creation of nature and along with the vision of human creation, which is a blessing of natural and natural blessings from God to His servants (Adesy, 2016).

\section{Trader Ethics}

Rasulullah when carrying out trade put manners and ethics forward. These ethics and trading traditions that can be called the strategy in trading including in the e-commerce era are as follows: First, Honest (transparent). In Islamic doctrine, honesty is the most basic requirement in business activities. Rasulullah is very intensely advocating honesty in business activities. With an honest attitude, the buyer's trust in the seller will be created by itself. Honest in a broader understanding means not lying, not deceiving, not making up facts, not betraying, and never breaking promises (Moh.Huzaini, 2017).

Second, Respecting the Buyer. A seller is obliged to pay homage to the consumer (buyer) and instead reciprocate the respect given to him (QS. An-Nisa '[4]: 86). Because in Islam the practice of buying and selling is basically an activity of helping to assist fellow human beings who have a strong foundation in the Qur'an, Sunnah and ijma '(QS. Al-Baqarah [2]: 198, Al-Baqarah [2]: 275, 


\section{Islamic Business Ethics As A Practical Solutions \\ In The Scope Of E-Commerce Business}

Havis Aravik, dkk

An-Nisa '[4]: 29). Help is a reflection of the righteous and the feeling of piety is the bond between the two parties that will give birth to compassion, fairness, honesty and trustworthiness.

Third, Fair to the Buyer. The core aim of Islam is to build a just, moral and passionate social order through human intermediaries. Because of this, individuals and communities are seen as interrelated (Iqbal, Zamir; Mirakhor, 2011), including interactions between sellers and buyers. Being fair to consumers is a must (QS. Al-Maidah [5]: 8) especially in determining the quality (quality) and size (quantity) at each dose and scale (QS. Al-An'am [6]: 152, Ar-Rahman [55]: 7-9). Moreover, the existence of the consumerism movement, which is a protest from consumers or the community, because the treatment of entrepreneurs who are not good in serving consumers is clear evidence of the importance of being fair to buyers (Alma, 2006).

Fourth, not to put too high prices. In Islamic economics, profit-taking must fulfill the fair element, as the word of God in Al-Qur'an surah Huud [11] verse 84. The verse can be understood that permitting profit-taking on business commerce must be based on aspects of justice so that it brings benefits to all parties. Opposing justice is an act that is detrimental to humans, depriving human rights and all actions that can cause damage to society. Thus, the fair is a basic value that applies to social life (social life). Imam al-Ghazali said it was forbidden to double prices (taking profits too high).

Fifth, don't think too much about profits. Imam al-Ghazali stated that one of the traits of a merchant is not to make more profit. Pursuing the highest profit is not wrong, but when the ambition to achieve high profit makes the other party losers, this has the potential to worsen business conditions. An example is the exploitation of consumers that makes consumers lose and the exploitation of nature that makes environmental damage, where these conditions can be a trigger for business unsustainability and deviate from the essence of business according to an Islamic perspective (Hijriah, 2016).

Sixth, Avoid Buying and Selling that is not allowed by Syara '. Islam requires traders not to do prohibited things such as talaqqi rukban (intercepting traders who bring goods from the place of production before reaching the market), Gisyah (hiding defects of goods sold or mixing defective 
products into quality goods), najasy (trading practices where someone pretends to be a buyer who bids high prices for goods accompanied by unnatural quality praise, with the aim of raising the price of goods), illicit products (QS. AlBaqarah [2]: 173, 219, Al-Maidah [5]: 3, Al-An'am [6]: 145, and An-Nahl [16]: 115), usury (Surah Al-Baqarah [2]: 275, 276, 278, 279, Ali Imran [3]: 130 and Ar-Rum [30]: 39) and Tathfif (actions that reduce the scale or quantity of goods to be sold, QS. Al-Muthaffifin [83]: 1-6)(Aravik, 2016) . Seventh, Keeping the Promise. A good trader is a trader who always keeps his promises when he promises, both to buyers and among business people, moreover, they must be able to keep their promises to Allah SWT. The intended promise is a promise where a businessman conducts his business transactions both to the buyer, and to his business partners (Moh.Huzaini, 2017)..

Eighth, Carrying out God's right that is required on the Material. The basic principle of ownership in Islam states that only Allah himself is the real owner of all ownership. So that humans can materially carry out their duties and obligations, humans are given the right to own. Therefore, Islam rejects the concept of the individualism which states that a person will not harm other members of society if that person becomes better due to his own efforts and other people do not get worse as a result of his efforts. According to Islam, private ownership contains rights and obligations, as well as trust. Personal initiatives, choices, and rewards are recognized in the conception of Islamic ownership. However, this recognition does not invalidate the principle of liability for various assets or ownership (Iqbal, Zamir; Mirakhor, 2011).

\section{Business Competition Ethics}

In the era of globalization which is marked by increasingly fierce competition, business people seem to prefer shortcuts by abandoning ethical values as long as their business is saved, rather than upholding ethics but then the corporate is out of business. This phenomenon can be understood, among others, from how the results of research such as those conducted both in the United States and in Indonesia. As an indication that nowadays moral norms almost certainly do not have a place in the hearts of business people. Selfishness is the same as moral fading which teaches concern for others (Moh.Huzaini, 2017). 


\section{Islamic Business Ethics As A Practical Solutions \\ In The Scope Of E-Commerce Business}

Havis Aravik, dkk

Today's increasingly fierce business competition requires the application of good business ethics. This is important because in the context of Islam the purpose of doing business is not merely to obtain the maximum profit, but also to seek pleasure and achieve blessings on the sustenance provided by Allah SWT. Rasulullah SAW has given an example of how to compete well. when trading, the Messenger of Allah never made a business that made his competitive business destroyed. It does not mean that the Prophet's trading style did not pay attention to competitiveness. In this case, Rasulullah provided the best service and stated honestly the specifications of the goods sold, including if there were defects. Naturally, this can improve the quality of sales and attract buyers without destroying other traders.

It must be recognized that the business world is full of competition, the rules in business will be different from the rules in social life. For this reason, Rasulullah SAW in the context of business competition provides the following recommendations: First, Muslim business actors must strive to provide the best service (customer-oriented). To be able to do this requires honesty, fairness, and trustworthiness in carrying out business contracts. If differences of opinion occur then it is resolved peacefully and fairly without any elements of fraud that can harm either party. So that customers can be satisfied, some things can be done such as, fair in weighing, showing defects in goods traded, avoiding oaths in buying and selling and not practicing what is called bai 'Najasy, namely praising and expressing the superiority of goods when their quality is not as good as those promoted, this also means lying to buyers (Norvadewi, 2015).

Second, Muslim business people are required to provide openness (transparency) and honesty in their business activities. One form of transparency, for example, is open about quality, quantity, composition, chemical elements, and others so as not to endanger and harm consumers and prohibit collusion in the business competition (QS. Al Baqarah [2]: 188, [7]: 85, Al-Baqarah [2]: 205). Ahmad Hulaimi, Sahri, and Moh. Huzaini (2017) said that being honest in a broader understanding is not lying, not cheating, not making up facts, and not betraying, and never breaking promises in conducting business transactions both to the buyer and to his business partners. 
Third, the Muslim business actors must pay attention to Islamic laws relating to business contracts such as being fair to others. Examples of fairness to consumers by not committing fraud and causing harm to consumers. The manifestation of justice for employees is to provide fair wages for employees, not exploit them and protect their rights and so on (Norvadewi, 2015). Fourth, for a Muslim, business is carried out in order to obtain and develop ownership of property. The treasure obtained is a gift that has been determined by Allah SWT. Every soul has its respective fortune determined so it is not possible to be exchanged with others. Humans are only tasked to make efforts to fetch good fortune and do business without having to violate existing norms (QS. Al-Mulk [67]: 15). Therefore, the process of seeking sustenance for a Muslim is an obligation and the process undertaken in the context of seeking sustenance must be made as a means to draw closer to Allah SWT.

Fifth, a Muslim must view business as carrying out Allah's commands. to scatter on the face of the earth in search of His gifts. Thus, it did not occur to him to justify any means to simply win the competition. For Muslim business actors, competition means competing to be the best. The best before God is achieved with all his strength to remain faithful to obey each of His rules in doing business, while the best before humans by doing business with quality products, competitive prices, and with maximum service (QS. An-Naba '[78 ]: 10-11).

\section{Marketing Ethics}

The Indonesian Bankers Association in Sharia Bank Business Strategy, states that there are some things that must be considered by marketers in carrying out business activities so as not to violate the sharia principles in their marketing activities by avoiding the following: First, Bribery (risywah) and all matters related to bribery. Risywah is a gift that leads to batil (illegal) and there is an element of taking rights that are not their rights. In other words, giving something to other parties to get something that is not their right. Bribery is illegal and is against Islamic law. Rasulullah SAW said: "From Abu Abdullah Ibn Amr said; that Rasulullah SAW has said: Those who bribe and those who take bribes are both going to hell. " (Narrated by Imam Thabrani). Second, Supply manipulation (Ikhtikar). Ikhtikar is an attempt to take profits above-normal 


\section{Islamic Business Ethics As A Practical Solutions \\ In The Scope Of E-Commerce Business}

Havis Aravik, dkk

profits by selling (production) less so that the goods experience scarcity for the purpose of increasing higher prices. ikhtikar violations solely because of motivation or the purpose of making greater profits and wrong consumers. Islam strictly prohibits ikhtikar activities. The Prophet Muhammad SAW said: "It is not for someone who is hoarding for-profit purposes unless he is a sinner (sin)" (HR. Muslim).

Third, Manipulation of Requests (najasy). Najasy is an attempt to take advantage of normal profits by creating false requests (demand manipulation). Najasy is done to get more benefits than normal profits as in the ikhtikar. Fourth, Culas and Cheat (tadlis). Transactions containing an unknown thing to one party (unknown to one party), especially the buyer, and harming the buyer in a transaction are called fraudulent or foul (tadlis). Tadlis are divided into four types: a). Quantity Tadlis, for example, reducing the dose or scale. b). Quality Tadlis, for example, hiding defects of goods that will be sold to consumers. c). Pricing, for example, taking advantage of buyer ignorance of market prices. d). Tadlis the time of delivery, for example, undertaking to deliver goods within a certain time that is believed/realized unable to fulfill it (Aravik, H., \& Hamzani, 2021).

\section{CONCLUSION}

From the description above it can be understood that industrial revolution 4.0 is a historical necessity including e-commerce based business activities. For this reason, business activities must be based on standard rules. Islam as rahmatan lilalamin religion, has given guidance to every human, especially to all Muslims that in business activities there is an Islamic ethic inherent in it. The ethics are intended so that business activities do not solely produce material benefits, but more than that create more benefits that are achieved in both the world and the hereafter. Therefore, Islam really regulates various business activities such as production, consumption, trading, competing in business to market a product to consumers. 


\section{REFERENCES}

Adesy, dan Fordebi. (2016). Ekonomi dan Bisnis Islam; Seri Konsep dan Aplikasi Ekonomi dan Bisnis Islam. Jakarta: PT. Raja Grafindo Persada.

Agustin, H. (2017). Studi Kelayakan Bisnis Syariah. Jakarta: PT. Raja Grafindo Persada.

Ahmad Yusuf Marzuqi, A. B. L. (2010). Manajemen Laba dalam Tinjauan Etika Bisnis Islam. Jurnal Dinamika Ekonomi \& Bisnis, 7(1), 1-22. https://doi.org/10.34001/jdeb.v7i1.121

Alma, B. (2006). Kewirausahaan; Menumbuhkan Jiwa Wirausaha bagi Mahasiswa dan Masyarakat Indonesia. Bandung: Alfabeta.

Aravik, H., \& Hamzani, A. (2021). Etika Perbankan Syariah: Teori dan Implementasi. Deepublish.

Aravik, H. (2016). Ekonomi Islam: Konsep, Teori dan Aplikasi serta Pandangan Pemikiran Ekonomi Islam dari Abu Ubaid sampai alMaududi. Empat Dua Intranspublishing.

Bahri S., A. (2014). Etika Konsumsi Dalam Perspektif Ekonomi Islam. HUNAFA: Jurnal Studia Islamika, 11(2), 347. https://doi.org/10.24239/jsi.v11i2.360.347-370

Hijriah, H. Y. (2016). Spiritualitas Islam dalam Kewirausahaan. Tsaqafah, 12(1), 187. https://doi.org/10.21111/tsaqafah.v12i1.374

Iqbal, Zamir; Mirakhor, A. (2011). An Introduction to Islamic Finance: Theory and Practice. John Wiley \& Sons.

Kadir, A. (2013). Hukum Bisnis Syariah dalam Al-Qur'an. Jakarta: Amzah.

Kasali, R. (2017). Distruption; Menghadapi Lawan-Lawan Tak Kelihatan dalam Peradaban Uber. PT. Gramedia Pustaka Utama.

Machmud, A. (2017). Ekonomi Islam Untuk Dunia yang Lebih Baik. Jakarta: Salemba Empat.

Moh.Huzaini, A. H. S. (2017). Etika Bisnis Islam dan Dampaknya terhadap Kesejahteraan Pedagang Sapi. Jurnal Ekonomi Dan Bisnis Islam, 2(1), 1. https://doi.org/10.15548/jebi.v2i1.64

Norvadewi. (2015). Bisnis Dalam Perspektif Islam (Telaah Konsep, Prinsip dan Landasan Normatif). AL-TIJARY : Jurnal Ekonomi Dan Bisnis Islam, 1(1), 33-46. https://doi.org/10.21093/at.v1i1.420

Saifullah, M. (2011). Etika Bisnis Islami dalamPraktek Bisnis Rasulullah. Walisongo: Jurnal Penelitian Sosial Keagamaan, 19(1), 127-156. 


\section{Islamic Business Ethics As A Practical Solutions}

In The Scope Of E-Commerce Business

Havis Aravik, dkk

hhttp://dx.doi.org/10.21580/ws.19.1.215

Sudaryono. (2015). Pengantar Bisnis; Teori dan Contoh Kasus. Yogyakarta: Andi Offset.

Suwardana, H. (2018). Revolusi Industri 4. o Berbasis Revolusi Mental. JATI UNIK : Jurnal Ilmiah Teknik Dan Manajemen Industri, 1(2), 109-118. https://doi.org/10.30737/jatiunik.v1i2.117

Zamzam, H. F., \& Aravik, H. (2020). Etika Bisnis Islam Seni Berbisnis Keberkahan. Deepublish. 